DOI: https://doi.org/10.24127/ajpm.v8i3.2270

\title{
ANALISIS PROSES BERPIKIR SISWA DALAM MEMECAHKAN SOAL CERITA STATISTIKA
}

\author{
Baiq Rika Ayu Febrilia ${ }^{1}$, Eliska Juliangkary ${ }^{2}$, Baiq Dewi Korida ${ }^{3^{*}}$ \\ 1,2,3 Pendidikan Matematika, IKIP Mataram \\ *Corresponding author. Address: Department of Mathematics Education, IKIP Mataram, Nusa Tenggara Barat, \\ Indonesia, 83125.
E-mail: $\quad$ rikafebrilia@ikipmataram.ac.id ${ }^{1)}$ eliska01juliangkary@gmail.com $^{2}$
baiqdewikorida12@gmail.com $^{3 *}$

Received 05 Sept 2019; Received in revised form 6 December 2019; Accepted 31 December 2019

\begin{abstract}
Abstrak
Penelitian ini bertujuan untuk mendeskripsikan proses berpikir siswa dalam memecahkan soal cerita statistika ditinjau dari segi pemahaman soal dan strategi yang digunakan oleh siswa dalam menyelesaikan permasalahan tersebut. Subjek yang terlibat sebanyak 13 orang mahasiswa Program Studi Pendidikan Matematika IKIP Mataram, di mana 8 diantaranya berjenis kelamin laki-laki dan 5 lainnya berjenis kelamin perempuan. Data dikumpulkan melalui instrumen soal pada materi statistika sub pokok bahasan mengenai rata-rata dari suatu data. Analisis data dilakukan secara kualitatif pada lembar jawaban setiap subjek dengan fokus dalam menggambarkan dua bagian utama dari tahapan Polya, yaitu tahapan pemahaman soal dan strategi yang digunakan dalam menjawabnya dibantu dengan indikator proses berpikir. Hasil penelitian menunjukkan bahwa sebagian besar subjek memiliki proses berpikir semikonseptual baik dari segi pemahaman maupun strategi yang digunakan, sedangkan hanya satu orang subjek yang memiliki proses berpikir konseptual.
\end{abstract}

Kata kunci: Pemecahan soal; proses berpikir; statistika.

\begin{abstract}
This study aims to describe the students' thought processes in solving statistical story problems in terms of understanding the questions and strategies used by students in solving these problems. The subjects involved were 13 students of the Mathematics Education Study Program IKIP Mataram, in which 8 of them were male and 5 were female. Data is collected through a matter of statistical instruments sub subject matter about the average of a data. Data analysis was carried out qualitatively on the answer sheets of each subject with a focus on describing the two main parts of the Polya stage, namely the stage of understanding the questions and the strategies used in answering them assisted with thought process indicators. The results showed that most subjects had a semiconceptual thought process both in terms of understanding and the strategies used, while only one subject had a conceptual thinking process.
\end{abstract}

Keywords: problem solving; thought processes; statistics.

\section{PENDAHULUAN}

Proses berpikir siswa merupakan hal yang menarik untuk diobservasi dan dieksplorasi lebih jauh. Sifatnya yang sangat abstrak mengakibatkan tidak banyak guru yang merasa kesulitan dalam melaporkan langkah demi langkah dari tahapan berpikir siswanya. Pemahaman yang baik terhadap proses berpikir siswa mampu memberikan informasi kepada guru mengenai seberapa kritis (Ramalisa, 2013; Amir, 2015) dan kreatif (Siswono, 2016) siswa tersebut. Apabila terdapat kesalahpahaman dalam berpikir, maka guru perlu menelusuri apa jenis kesalahpahamannya dan menggali lebih jauh di tahapan mana letak kesalahpahaman serta apa saja yang menyebabkan hal itu bisa terjadi (Kafiar, Kho \& Triwiyono, 2015). Guru juga perlu mencari dan menginisiasi 
langkah apa yang perlu ditempuh untuk memperbaiki kesalahpahaman dan mencegah hal serupa dapat terjadi pada siswa itu dan siswa yang lain pada umumnya (Rizal, 2011). Dengan kata lain, proses berpikir dapat dijadikan sebagai ukuran sejauh mana pemahaman konten siswa (Ngilawajan, 2013).

Soal cerita merupakan salah satu permasalahan yang dapat mendorong keterampilan berpikir siswa (Farida, 2015), sehingga perhatian yang besar mengenai proses berpikir siswa dalam menyelesaikan permasalahan ini dipandang sangat dibutuhkan. Pemberian soal cerita dimaksudkan sebagai media untuk melatih siswa dalam menerapkan pemahaman konsep yang dimiliki melalui proses pembelajaran, termasuk dalam melatih kemampuan berpikir kritis dan mendorong kebermanfaatan matematika dalam menemukan solusi permasalahan di dunia (Karnasih, 2015) karena soal cerita biasanya dikemas dalam bentuk narasi dan berkaitan dengan konteks kehidupan sehari-hari. Penelitian mengenai proses berpikir siswa dalam menyelesaikan soal cerita telah banyak dilakukan, diantaranya Istiqomah \& Rahaju (2014) yang meneliti tentang proses berpikir siswa Sekolah Menengah Pertama (SMP) dalam menyelesaikan materi Bangun Ruang Sisi Lengkung berdasarkan gaya kognitif dengan menggunakan indikator proses berpikir konseptual, semikonseptual dan komputasional. Yanti \& Syazali (2016) juga menggunakan indikator proses berpikir yang sama untuk menggambarkan proses berpikir siswa dalam menyelesaikan soal cerita. Akan tetapi, materi yang dijadikan sebagai fokus penelitian adalah Sistem Persamaan Linier Dua Variabel (SPLDV) dengan subjek penelitian siswa pada Madrasah Aliyah (MA) ditinjau dari Adversity Quotient. Berbeda dengan dua penelitian ini, Sirait, Jamiah \& Suratman (2017) menggunakan tahapan Polya sebagai indikator proses berpikir siswa Sekolah Menengah Atas (SMA) berkemampuan tinggi, sedang dan rendah pada materi Sistem Persamaan Linier Tiga Variabel (SPLTV).

Dari ketiga penelitian tersebut, fokus masalah yang diujikan belum memuat konten Statistika. Padahal materi ini merupakan salah satu materi yang sering kali menggunakan soal cerita dalam narasi pertanyaannya. Dari segi subjek penelitian, subjek yang terlibat masih dalam rentang sekolah menengah, sedangkan permasalahan mengenai penyelesaian soal cerita juga menjadi masalah besar bagi mahasiswa di berbagai tingkatan dan jurusan. Kelemahan baik yang terjadi pada diri siswa dan mahasiswa dalam menyelesaikan soal cerita terutama untuk merubah bentuk atau narasi cerita menjadi ekspresi, kalimat atau model matematika (Laily, 2014), sehingga ini berakibat pada rendahnya kemampuan siswa dalam memahami peran penting matematika dalam kehidupan mereka sehari-hari (Farida, 2015). Dalam menyelesaikan permasalahan ini, baik siswa maupun mahasiswa kerap kali melakukan kesalahan, yang mana kesalahan terbesar adalah dalam melaksanakan rencana yang telah disusun, diikuti dengan kesalahan menyusun rencana, memeriksa ulang solusi yang telah diperoleh dan kesalahan dalam memahami soal (Hidayah, 2016). Berbeda dengan hasil Hidayah (2016), penelitian Rindyana \& Chandra (2012) menyatakan bahwa kesalahan terbesar dalam menyelesaikan soal cerita adalah kesalahan memahami masalah dan 
membaca soal. Masalah bahasa juga termasuk salah satu pemicu sulitnya siswa dalam menyelesaikan soal cerita, seperti salah dalam menginterpretasikan kalimat dalam soal (Marlina, 2013).

Hal ini didukung oleh fakta bahwa mahasiswa tahun kedua Program Studi Pendidikan Matematika IKIP Mataram, saat menempuh perkuliahan Statistika Dasar, hanya mampu mencapai nilai $\mathrm{C}+$ hingga $\mathrm{B}+$, sedangkan pada mahasiswa tahun ketiga nilai Statistika Dasar mahasiswa berada pada rentang dari $\mathrm{E}$ hingga A-, yang mana nilai E sebanyak 7 orang, nilai D sebanyak 3 orang, C+ sebanyak 1 orang, B- sebanyak 4 orang, B sebanyak 3 orang, B+ sebanyak 3 orang dan A- hanya diperoleh oleh satu orang dari 22 orang mahasiswa yang aktif mengikuti proses kuliah. Beragamnya nilai mahasiswa menunjukkan perbedaan proses berpikirnya dan masih banyaknya siswa yang memiliki nilai di bawah $B$ menunjukkan masih rendahnya kemampuan siswa dalam menyelesaikan permasalahan yang diberikan, salah satunya pada permsalahan dalam bentuk soal cerita.

Untuk memahami dengan baik proses berpikir mahasiswa terhadap soal cerita statistika, maka diperlukan suatu analisis proses berpikir yang dapat menggambarkan proses tersebut pada uraian jawaban mahasiswa. Analisis proses berpikir dapat dilakukan dengan mengkategorikan proses tersebut secara konseptual (siswa menggunakan pemahaman konsep yang baik dan mendalam untuk menyelesaikan permasalahan yang diberikan), semikonseptual (siswa menggunakan konsep dan intusi dalam menyelesaikan masalah karena pemahaman konsep yang belum lengkap) dan komputasional (siswa menggunakan intuisi dalam menyelesaikan suatu permasalahan) (Yanti \& Syazali, 2016). Penelitian lain mengkategorikan proses berpikir siswa dalam menyelesaikan permasalahan berdasarkan empat tahapan Polya, yaitu pemahaman masalah, penyusunan rencana penyelesaian, pelaksanaan rencana penyelesaian dan pemeriksaan kembali (Safrida, Susanto \& Kurniati, 2015; Indrawati, Muzaki \& Febrilia, 2019). Kedua cara dalam mengkategorikan proses berpikir siswa ini merupakan dua cara pandang yang berbeda yang dapat diadaptasi untuk menghasilkan suatu gambaran yang baik dalam memahami langkah demi langkah dari pemahaman siswa.

Berdasarkan uraian di atas, maka fokus dari penelitian ini adalah untuk menganalisis proses berpikir mahasiswa dalam memecahkan soal cerita statistika. Penelitian ini diharapkan dapat memberikan kontribusi pengetahuan mengenai macam-macam proses berpikir mahasiswa terhadap jenis soal yang diberikan, langkah yang dilakukan dalam menjawab permasalahan dan kesalahan-kesalahan yang dilakukan mahasiswa selama proses menjawab permasalahan tersebut.

\section{METODE PENELITIAN}

Jenis penelitian ini adalah kualitatif deskriptif yang bertujuan untuk menganalisis proses berpikir siswa dalam memecahkan soal cerita pada materi statistika. Hasil analisis proses berpikir dikelompokkan dari segi pemahaman soal dan strategi yang digunakan. Subjek yang terlibat sebanyak 13 orang mahasiswa Program Studi Pendidikan Matematika IKIP Mataram, di mana 8 diantaranya berjenis kelamin laki-laki dan 5 lainnya berjenis kelamin perempuan. Mahasiswa ini dipilih secara acak dan 
diperoleh informasi bahwa 4 dari mahasiswa tersebut merupakan mahasiswa tahun pertama, tujuh mahasiswa tahun kedua dan 2 mahasiswa tahun ketiga. Mahasiswa ini selanjutnya disebut sebagai siswa.

Berkaitan dengan teknik pengumpulan data, digunakan satu instrumen soal pada materi statistika sub pokok bahasan mengenai rata-rata dari suatu data. Soal ini memberikan narasi mengenai lima nilai tes seorang anak, Andi, pada mata pelajaran tertentu. Andi mendapatkan kesempatan untuk mengganti nilai terendah dan tertinggi dengan satu nilai pada ujian akhir. Instruksi yang diminta dalam soal adalah menentukan nilai terendah yang harus diperoleh Andi, jika Andi memilih untuk mengambil ujian akhir dan mempertahankan nilai rata-rata yang telah dimiliki saat ini. Redaksional soal secara lebih rinci ditunjukkan pada Gambar 1.

Andi memiliki nilai tes $90,88,82,77,75$ dan 74 . Gurunya menggunakan nilai rata-rata tes sebagai nilai akhir kelas. Andi memiliki opsi untuk mempertahankan rata-rata tes saat ini atau mengganti nilai tertinggi dan terendah yang saat ini ia miliki dengan satu skor pada ujian akhir. Jika Andi memilih untuk mengambil ujian akhir. Temukan skor terendah yang dapat ia terima dan masih mempertahankan setidaknya rata-rata yang ia miliki saat ini.

Gambar 1. Masalah yang diberikan kepada subjek.

Analisis data dilakukan secara kualitatif pada lembar jawaban setiap subjek dengan fokus dalam menggambarkan dua bagian utama dari tahapan Polya, yaitu tahapan

Tabel 1. Kategori proses berpikir siswa.

\begin{tabular}{|c|c|c|}
\hline $\begin{array}{c}\text { Proses berpikir } \\
\text { konseptual }\end{array}$ & $\begin{array}{l}\text { Proses berpikir } \\
\text { semikonseptual }\end{array}$ & $\begin{array}{l}\text { Proses berpikir } \\
\text { komputasional }\end{array}$ \\
\hline $\begin{array}{l}\text { Subjek mampu } \\
\text { menuliskan informasi } \\
\text { yang diketahui dan } \\
\text { ditanyakan pada soal } \\
\text { menggunakan bahasanya } \\
\text { sendiri. }\end{array}$ & $\begin{array}{l}\text { Subjek kurang mampu } \\
\text { menuliskan informasi yang } \\
\text { diketahui dan ditanyakan } \\
\text { pada soal menggunakan } \\
\text { bahasanya sendiri. }\end{array}$ & $\begin{array}{l}\text { Subjek tidak mampu } \\
\text { menuliskan informasi yang } \\
\text { diketahui dan ditanyakan } \\
\text { pada soal. }\end{array}$ \\
\hline $\begin{array}{l}\text { Subjek mampu menjawab } \\
\text { permasalahan } \\
\text { menggunakan konsep } \\
\text { matematika yang telah } \\
\text { dipelajari. }\end{array}$ & $\begin{array}{l}\text { Subjek menjawab } \\
\text { permasalahan menggunakan } \\
\text { perpaduan antara sebagian } \\
\text { konsep matematika yang } \\
\text { telah dipelajari dan intuisi. }\end{array}$ & $\begin{array}{l}\text { Subjek menjawab } \\
\text { permasalahan menggunakan } \\
\text { langkah-langkah yang } \\
\text { berbeda dengan konsep } \\
\text { yang dipelajari dan } \\
\text { sebagian besar } \\
\text { menggunakan intuisi. }\end{array}$ \\
\hline
\end{tabular}

pemahaman soal dan strategi yang digunakan dalam menjawabnya dibantu dengan indikator proses berpikir yang diadaptasi melalui Yanti \& Syazali (2016) pada Tabel 1.

menggunakan intuisi. 
DOI: https://doi.org/10.24127/ajpm.v8i3.2270

\section{HASIL PENELITIAN DAN PEMBAHASAN}

Pada bagian ini dijelaskan lebih jauh mengenai hasil analisis dan pembahasan dari proses berpikir siswa ditinjau melalui pemahaman soal dan strategi yang digunakan.

\section{a. Pemahaman Soal}

Hasil deskripsi dan analisis jawaban subjek terhadap soal yang diberikan menunjukkan bahwa pemahaman atau interpretasi soal subjek berbeda-beda dan biasanya sesuai dengan pengetahuan yang dimiliki. Oleh karena itu, cara menyelesaikan permasalahan juga beraneka ragam, ada yang menjawab sesuai dengan konsep yang ada, ada yang mengandalkan konsep dan intuisi yang dimiliki serta ada juga yang mengandalkan hanya intuisi. Lebih jauh, hal ini menunjukkan bahwa proses berpikir dari setiap subjek yang terlibat berbeda-beda (Yanti \& Syazali, 2016).

Subjek 1 (S1) diduga memahami maksud soal yang diberikan, bahwa Andi diberikan dua pilihan untuk mendapatkan rata-rata terbaik. Pilihan pertama adalah mendapatkan rata-rata dengan menggunakan nilai yang sudah diperoleh dan pilihan kedua dengan mengganti dua nilai yang telah diperoleh (nilai tertinggi dan terendah) dengan satu nilai akhir. Dugaan ini diperkuat melalui cuplikan jawaban yang ditulis $\mathrm{S} 1$ seperti yang ditunjukkan pada Gambar 2.

Dalam gambar tersebut, S1 menghilangkan nilai tertinggi (90) dan terendah (74) dan menggantinya dengan satu variabel $(x)$ yang belum diketahui nilainya. Oleh karena terdapat pergantian 2 nilai menjadi satu nilai, maka banyaknya data semula yang ada sebanyak 6 diganti menjadi sebanyak 5 oleh S1. Selain itu, S1 juga memahami bahwa nilai pengganti nanti haruslah dapat membuat nilai rata-rata yang diperoleh melalui pilihan baru ini minimal sama dengan rata-rata awalnya. Berdasarkan penjelasan mengenai cara menyelesaikan masalah, S2 dapat dikategorikan kedalam proses berpikir yang konseptual karena ia telah mampu menyelesaikan permasalahan dengan langkah-langkah sesuai dengan soal yang diberikan, dan mampu dalam menyusun sebuah rencana apa yang harus dilakukan untuk menyelesaikan permasalahan sampai menemukan jawaban yang benar, walaupun tidak menuliskan apa yang diketahui dan ditanyakan pada soal (Retna \& Mubarokah, 2013).

$$
\operatorname{rata}^{(1)} \bar{x}=\frac{88+82+77+75+x}{5}
$$

Gambar 2. Hasil pekerjaan S1.

Sama halnya dengan S1, subjek 12 (S12) juga tidak menuliskan keenam nilai yang diperoleh Andi pada bagian diketahui dan ditanyakan, akan tetapi S12 masih belum memiliki pemahaman yang baik tentang bagaimana menyelesaikan permasalahan yang diberikan meskipun S12 dapat menuliskan, "Andi memiliki dua opsi untuk mempertahankan rata-rata tes yang nilainya 81 atau menggantikan nilai tertinggi dan terendah yang saat ini dengan satu skor pada ujian akhir". Setelah mencari nilai rata-rata dari nilai yang telah diperoleh sebelumnya dengan konsep yang sesuai dengan yang telah ada, selanjutnya $\mathrm{S} 12$ menyelesaikan permasalahan dengan cara mencari nilai rata-rata dari nilai tertinggi dan terendah saja kemudian secara langsung memperkirakan nilai $(\geq 72)$ yang akan menjadi nilai terendah yang dapat Andi terima. Dalam menyelesaikan permasalahan 
yang berhubungan dengan matematika, apalagi dengan soal yang membutuhkan proses yang tidak langsung maka perlu adanya sebuah pemahaman, skill (keterampilan), serta pengetahuan untuk dapat menjawab soal yang diberikan (Hartono, 2014). Berbeda dengan proses berpikir S1, dari hasil pekerjaan yang dilakukan oleh S12 menunjukkan bahwa proses berpikir yang dilakukan oleh S12 termasuk kedalam proses berpikir semikonseptual karena dalam menyelesaikan permasalahan S12 mengandalkan konsep (seperti pada saat mencari nilai rata-rata) dan intuisi pada saat mencari nilai terendah yang mungkin diterima Andi (Retna \& Mubarokah, 2013).

Subjek 2 (S2) mampu menuliskan keenam nilai tes yang telah diperoleh Andi, sedangkan pada bagian yang ditanyakan S2 tidak menuliskan secara tepat apa yang ditanyakan, karena berdasarkan urutan penulisan menunjukkan bahwa S2 bermaksud untuk mencari nilai terendah terlebih dahulu baru kemudian mencari ratarata. Padahal, rata-rata seharusnya dicari terlebih dahulu karena akan digunakan untuk mencari nilai terendah yang akan diterima oleh Andi apabila mengambil ujian akhir. Itu sebabnya matematika memiliki peranan peting dalam pemecahan masalah untuk mendapatkan hasil akhir yang tepat dan benar sesuai dengan langkahnya (Cai \& Lester, 2010). Langkah selanjutnya, S2 secara langsung menggunakan nilai rata-rata untuk melihat nilai terendah dan tertinggi dari kumpulan nilai Andi. S2 menjustifikasi langsung nilai terendahnya adalah 74, sedangkan nilai tertingginya adalah 90. Dengan kata lain S2 menggunakan nilai rata-rata sebagai pembanding dengan nilai rata-rata yang telah diperoleh Andi sebelumnya kemudian ia menentukan dari nilai-nilai tersebut manakah nilai terendah dan tertingginya seperti pada Gambar 3. Proses berpikir yang sesuai dengan hasil jawaban yang telah dilakukan S2 dalam menyelesaikan permasalahan yang diberikan termasuk juga kedalam proses berpikir semikonseptual karena pada S2 saat memulai menyelesaikan permasalahan sudah mampu berpikir untuk menuliskan apa yang diketahui dan ditanyakan pada soal, dan bisa mencari nilai rata-rata dengan konsep yang sudah ada walapun penyelesaian akhirnya hanya mengandalkan intuisi saja (Retna \& Mubarokah, 2013).

$$
\begin{aligned}
& \text { Oleh karenan rata-rata yang diporobh Aneli adalah } \\
& \text { 81. maka untuk nilai Andi young puling terendah aialah } \\
& \text { 74. Srctangkan, untuk milai yaug tartinggi yaug dimilaki } \\
& \text { aidah } 90 \text {. }
\end{aligned}
$$

Gambar 3. Hasil pekerjaan S2.

Begitu juga dengan Subjek 13 (S13), walaupun memang diduga masih belum mampu dalam menjawab soal cerita, akan tetapi bukan berarti S13 tidak memahami apa yang harus dilakukan terlebih dahulu, seperti menuliskan keenam nilai yang diperoleh Andi pada bagian yang diketahui dan menuliskan apa yang ditanyakan pada soal lengkap dengan informasi penting 
yang termuat dalam soal seperti nilai terendah yang akan Andi terima apabila mengikuti ujian akhir dan tetap mempertahankan nilai rata-rata yang diperoleh sebelumnya. Bedanya dengan jawaban S2, S13 malah mencoba memecahkan masalah dengan rumus yang dibuatnya sendiri bukan berdasarkan konsep yang telah ada sebelumnya. Hasil analisis yang telah dilakukan menunjukkan bahwa S13 sudah mampu dalam menuliskan apa yang diketahui dan ditanyakan dalam soal dengan lengkap, akan tetapi lebih banyak mengandalkan intuisi, oleh karena itu dapat disimpulkan bahwa proses berpikir yang dimiliki S13 adalah proses berpikir semikonseptual (Retna \& Mubarokah, 2013).

Lembar jawaban yang dianalisis menunjukkan bahwa subjek 3 (S3) menuliskan keenam nilai tes yang telah diperoleh Andi (lihat Gambar 4) tetapi gambaran mengenai pemahaman subjek tidak dapat dijelaskan lebih jauh karena subjek tidak menuliskan apa yang ditanyakan pada soal dan tambahan informasi penting lain yang dapat digunakan untuk memecah masalah atau solusi dari permasalahan Andi. Meskipun demikian, analisis jawaban secara menyeluruh memberikan informasi bahwa S3 diperkirakan tidak memiliki pemahaman yang baik terhadap soal. Hal ini dikarenakan S3 mencoba untuk mencari alternatif nilai terendah dan tertinggi yang mungkin diperoleh Andi sehingga dia bisa mempertahankan nilai rata-rata sebelumnya. Jawaban ini tidak sesuai dengan yang diekspetasikan oleh soal. Hal ini juga dilakukan oleh Subjek 4 (S4), Subjek 5 (S5), Subjek 7 (S7), Subjek 8 (S8), Subjek 9 (S9) dan Subjek 10 (S10) yang menggunakan alternatif berbeda-beda berdasarkan cara berpikir masing-masing subjek dalam menyelesaikan permasalahan yang berbeda pula, sehingga menghasilkan jawaban yang bervariasi juga (Yanti \& Syazali, 2016). Proses berpikir dari semua subjek tersebut dapat dikategorikan kedalam proses berpikir semikonseptual karena dalam langkahlangkah yang digunakan masih mengandalkan intuisi saja kecuali pada bagian mencari nilai rata-rata yang mungkin akan diterima Andi (Retna \& Mubarokah, 2013).

\section{Nhlai tes: $90 \quad 8882 \quad 77 \quad 75 \quad 74$}

Gambar 4. Hasil pekerjaan S3.

Selanjutnya juga berdasarkan hasil analisis pada lembar jawaban Subjek 6 (S6) menunjukkan bahwa ia mengetahui bahwa nilai terendah Andi adalah 74 dan nilai tertingginya adalah 90. Pada bagian diketahui, S6 juga menuliskan rata-rata data sebesar 81, sedangkan pada bagian ditanyakan tertulis mengenai skor ujian akhir. Sama halnya dengan yang dilakukan S6, S11 juga menuliskan nilai terendah dan tertinggi pada bagian yang diketahui, tetapi S6 tidak menuliskan apa yang ditanyakan dalam soal. Di sini, S6 dan S11 memiliki usaha untuk menganalisis secara detail mengenai soal yang diberikan, serta mengumpulkan informasi penting terkait dengan soal tersebut agar lebih mudah dalam menyelesaikannya (Chukwuyenum, 2013).

\section{b. Strategi yang dilakukan atau proses}

Dalam menyelesaikan permasalahan, langkah pertama yang dilakukan S1 adalah mencari nilai ratarata dari nilai tes yang diperoleh, yaitu $90,88,82,77,75$ dan 74 . Nilai rata-rata 
tersebut menjadi panduan untuk mendapatkan satu nilai pada ujian akhir.

Seperti yang telah dipaparkan sebelumnya, S1 mengganti nilai tertinggi dan terendah dengan variabel $x$ dan diperoleh hasil $x=83$. Nilai inilah yang menjadi nilai terendah yang harus diterima Andi. Jawaban yang dihasilkan merupakan jawaban yang benar karena memiliki jiwa kreatif yang tinggi dalam memahami maksud soal, strategi yang digunakan tepat, serta dengan pengelihatan yang dapat secara cepat menganalisis apa maunya soal (Susiana, 2010).

Berbeda dengan cara penyelesaian S1, S3 menyelesaikan permasalahan dengan menggunakan dua opsi, dimana opsi ini dimungkinkan berfungsi sebagai langkah-langkah penyelesaian masalah. Pada opsi pertama, S3 mencari nilai rata-rata dari keenam nilai tes yang diperoleh Andi, sedangkan pada opsi kedua, S3 mencari nilai terendah dan tertinggi yang dapat mempertahankan nilai rata-rata saat ini jika Andi berencana untuk mengambil ujian akhir. Langkah yang dilakukan pada opsi pertama adalah langkah awal yang juga dilakukan oleh S1. Akan tetapi, pada bagian itu S3 menuliskan bahwa pentingnya untuk mengurutkan nilai ujian Andi dari terkecil hingga terbesar terlebih dahulu. Tidak ada penjelasan lebih jauh mengenai hal ini, namun salah satu alasan yang mungkin adalah S3 mencampur adukkan pemahaman konsep rata-rata dan median. S5 juga menggunakan langkah yang sama dengan S3, akan tetapi perubahan nilai tertinggi dan terendahnya berbeda. Pada bagian ini, S5 memberikan rentang nilai tertinggi yaitu dari 90 sampai 99, sedangkan nilai terendah berada pada rentang 70 sampai 79. Hasil analisis data menunjukkan bahwa strategi yang dilakukan oleh S3 dan S5 hampir sama pada saat menyelesaikan permasalahan yang diberikan bahwa ia hanya mampu menuliskan apa yang diketahui saja tanpa menuliskan apa yang ditanyakan, mengandalkan konsep pada saat mencari nilai rata-rata serta lebih cenderung mengandalkan intuisi pada saat menyelesaikan permasalahan sampai menemukan jawaban akhir. Proses seperti ini dapat dikategorikan pada proses berpikir semikonseptual (Retna \& Mubarokah, 2013).

Strategi yang digunakan S10 dalam menyelesaikan permasalahan adalah dengan mencari rata-rata skor Andi saat ini, kemudian mengganti nilai terendah dan tertinggi Andi dengan nilai rata-rata tersebut. Setelah itu, S10 mencari nilai rata-rata Andi yang baru dan diperoleh 80,67, hal ini serupa juga diperoleh oleh S9. Berbeda dengan S10, S9 langsung menjustifikasi nilai ratarata Andi setelah mengikuti ujian akhir sebesar 80,67 tanpa memberikan alur atau proses perolehan tersebut. S9 juga berargumen bahwa kesimpulannya jika Andi memilih untuk mengambil ujian akhir maka nilainya akan kurang dari rata-rata sebelumnya. Langkah kedua subjek ini jelas keliru karena jelas bahwa jika kita mengganti nilai terendah dan tertinggi dengan nilai ratarata maka rata-rata yang baru tidak akan mempertahankan rata-rata sebelumnya. Lagi pula, rata-rata tidak bisa dijadikan patokan dalam menentukan nilai ujian akhir Andi dalam kasus ini. Dilihat dari penjelasan tersebut, proses berpikir yang digunakan dikategorikan kedalam proses berpikir semikonseptual karena ia tidak hanya mengandalkan intuisi saja akan tetapi menggunkan konsep yang memang sudah ada pada saat mencari nilai rata-rata. 
DOI: https://doi.org/10.24127/ajpm.v8i3.2270

Langkah pertama yang dilakukan S7 adalah mencari nilai ratarata ujian Andi.Setelah itu, S7 menghilangkan nilai terendah dan tertinggi sehingga banyaknya ujian Andi saat ini hanya 4 ujian. S7 kemudian mencari rata-rata dari 4 ujian ini dengan hasil 80,5 dan menyimpulkan nilai tertingginya adalah 88 dan terendah 75 . Terdapat cara menyelesaikan permasalahan yang hampir sama dengan Subjek 11, perbedaannya terlihat pada strategi yang dilakukan S11 dalam mencari nilai terendah dari ujian akhir Andi adalah dengan mencari rata-rata dari nilai terendah dan tertinggi Andi. Cara ini kurang tepat karena meskipun nilai tersebut menghasilkan nilai yang dapat meningkatkan rata-rata Andi, tetapi nilai ini bukanlah nilai minimum yang harus Andi dapatkan. Oleh karena itulah proses belajar ini dapat dikelompokkan kedalam proses belajar semikonseptual karena S7 dan S11 juga menggunakan intuisi dalam menyelesaikan permasalahan selain mengandalkan konsep yang telah ada sebelumnya dalam mencari rata-rata.

S8 mencari rata-rata dari keenam nilai Andi, kemudian memisalkan rentang nilai tertinggi Andi dari 85-95 dan nilai terendah dari 74-84. Setelah itu, S8 menghitung nilai terendah dengan menggunakan rumus rata-rata tanpa mengikutsertakan dua nilai tertingginya. Rata-rata ini yang menjadi patokan nilai terendah Andi, strategi yang dilakukan S8 kurang tepat karena mencari nilai minimal yang seharusnya Andi peroleh saat ujian akhir tidak sama dengan rata-rata Andi mengilangkan dua nilainya. Dilihat dari hasil pekerjaan yang telah dilakukan S8, proses berpikir yang dilakukannya termasuk kedalam proses berpikir semikonseptual karena ia diduga mencampurkan antara intuisi dan penggunaan konsep dalam menyelesaikan permasalahan seperti mencari nilai rata-rata (Gambar 5).

Sama halnya dengan S1, S4 menyelesaikan permasalahan diawali dengan mencari nilai rata-rata Andi sebelum mengikuti tes akhir. Nilai ratarata yang didapatkan menjadi patokan dalam mencari nilai terendah yang akan diterima Andi. Akan tetapi, S4 secara langsung menuliskan bahwa nilai tertinggi yang diperoleh adalah nilai terbesar kedua (88) dan nilai terendah yang diperoleh dari nilai terkecil kedua (79). Lebih jauh, Gambar 5 menyediakan informasi bahwa setelah S4 menjustifikasi nilai terendah dan tertinggi, S4 kemudian mencari lagi nilai terendahnya dengan menggunakan nilai rata-rata dari 5 nilai Andi dan menghilangkan satu nilai yaitu nilai 88 . Untuk nilai tertinggi, S4 juga mencari nilai rata-rata dari 5 nilai Andi tetapi untuk bagian ini yang dihilangkan adalah nilai 75. Dari kedua perhitungan ini, S4 menyimpulkan bahwa nilai terendah yang didapat Andi 79,6 dan tertinggi 82,2. 


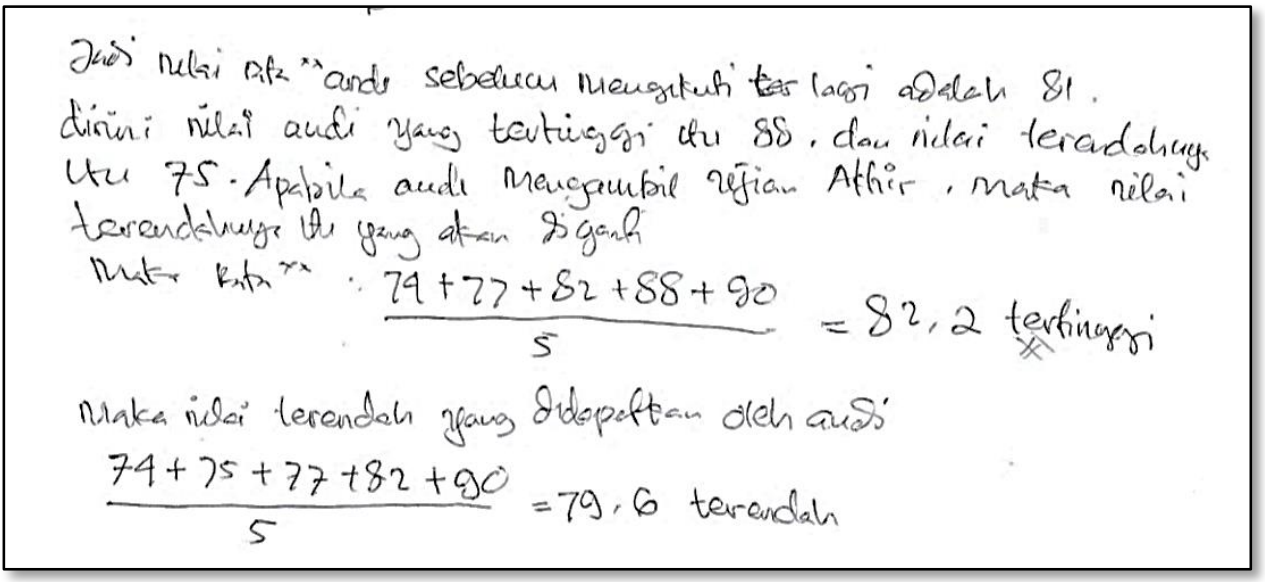

Gambar 5. Hasil pekerjaan S4.

Sama halnya dengan S1, S2 menyelesaikan permasalahan diawali dengan mencari rata-rata dari keenam nilai tes yang diperoleh Andi. Akan tetapi, pada langkah berikutnya S2 menggunakan langkah yang jauh berbeda dari S1 karena S2 secara langsung menggunakan nilai rata-rata untuk melihat nilai terendah dan tertinggi dari kumpulan nilai Andi. S2 menjustifikasi langsung nilai terendahnya adalah 74 , sedangkan nilai tertingginya adalah 90. Dengan kata lain S2 menggunakan nilai rata-rata sebagai pembanding dengan nilai rata-rata yang telah diperoleh Andi sebelumnya kemudian ia menentukan dari nilai-nilai tersebut manakah nilai terendah dan tertingginya.

Penyelesaian yang dipilih oleh S6 adalah mencoba-coba dalam menentukan satu nilai tersebut melalui menguji beberapa nilai sampai akhirnya memutuskan nilai tersebut adalah 82 kemudian membuktikan bahwa kombinasi empat nilai lain dan 82 akan menghasilkan rata-rata lebih dari 81 . Meskipun pemahaman dan langkah yang dimiliki S6 tidak keliru, tetapi S6 lupa untuk memeriksa kembali apakah dengan menukar nilai tertinggi dan terendah Andi dengan 82 itu akan membuat nilai rata-rata Andi minimal tetap dengan rata-rata sebelumnya. Sebenarnya S6 melakukan kesalahan perhitungan, yang mana rata-rata seharusnya setelah penggantian adalah sebesar 80,8. Nilai ini nyatanya lebih kecil dari nilai sebelumnya. Sebenarnya ia telah memulai dengan menggunakan konsep dalam mencari nilai rata-rata yang ada sebelumnya, akan tetapi pada saat mencari nilai terendah yang mungkin diterima oleh Andi, S6 juga mengandalkan intuisi. Oleh karena itu, proses berpikir ini dikategorikan kedalam proses berpikir semikonseptual (Retna \& Mubarokah, 2013).

Dalam menyelesaikan permasalahan, S12 memulai dengan mencari nilai rata-rata dari nilai yang telah diperoleh Andi sama seperti subjek yang lain. Kemudian, S12 menentukan nilai tertinggi (90) dan nilai terendah (74) dan mencari rata-rata dari nilai tersebut yang menghasilkan 82 . Pada tahap berikutnya, S12 secara langsung menuliskan nilai terendah yang mungkin didapatkan Andi adalah $\geq 72$ karena S12 berpikir bahwa maksud soal yang diberikan untuk mengganti nilai tertinggi dan terendah dengan satu nilai dan tetap mempertahankan nilai rata-rata adalah ketika mencari nilai rata-rata dengan mengganti nilai terendah (72) dan 
menetapkan nilai tertinggi (90) akan menghasilkan rata-rata nilai yang tetap yaitu 81 (Gambar 6). Oleh karena S12 dalam mencari nilai rata-rata sesuai dengan konsep yang ada sebelumnya sudah tepat akan tetapi pada saat menyelesaikan permasalahan untuk mencari nilai terendah yang akan diterima Andi hanya mengandalkan intuisi saja, tidak mampu dalam menggunakan langkah yang tepat, proses berpikir yang seperti itu dapat dikategorikan kedalam proses berpikir semikonseptual (Retna \& Mubarokah, 2013).

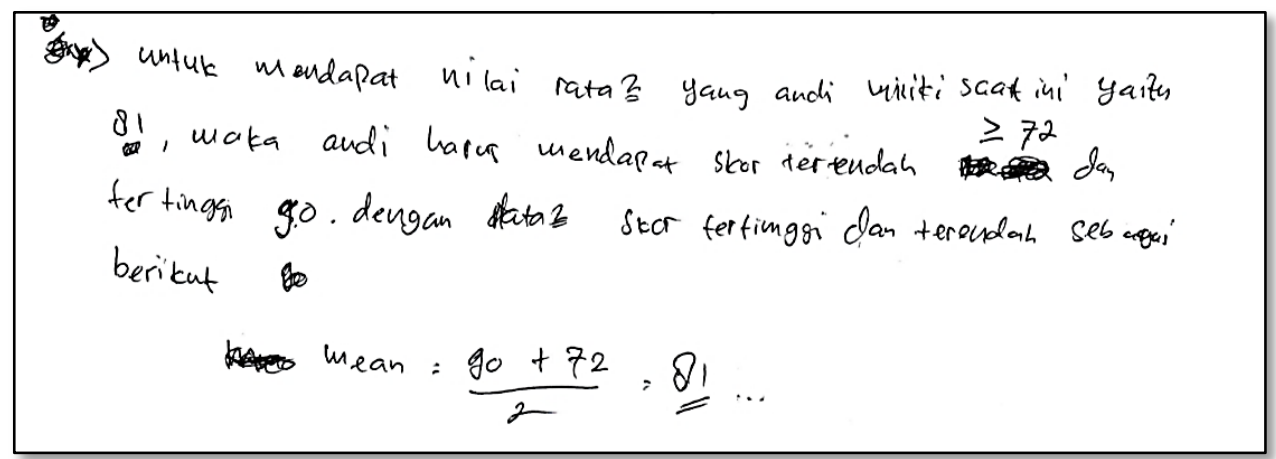

Gambar 6. Hasil pekerjaan S12.

Berbeda dengan subjek-subjek yang sebelumnya, setelah mencari nilai rata-rata langkah selanjutnya yang dilakukan S13 dalam menyelesaikan permasalahan yaitu dengan mencari nilai terendah yang akan diperoleh Andi menggunakan rumus yang tidak jelas dan acak-acakan. Setelah itu, seperti pada Gambar 7, dapat dilihat adanya kesalahan dalam penggunaan rumus atau metode yang sesuai, dimana S13 membuat rumus baru yang menurutnya benar, setelah itu mensubstitusikan nilai yang diketahui kedalam rumus tersebut yang menghasilkan 68,7. Jelas bahwa hasil dari rumus yang digunakan salah maka jawaban akhirnya akan salah juga. Kemudian, S13 menjustifikasi bahwa nilai inilah yang menjadi nilai yang akan diterima Andi apabila mengambil ujian akhir. Proses belajar seperti itu dapat dikelompokkan kedalam proses belajar semikonseptual dimana ia mengandalkan intuisi untuk menyelesaikan permasalahan dengan sedikit penggunaan konsep yang ada sebelumnya dalam mencari nilai ratarata (Retna \& Mubarokah, 2013).

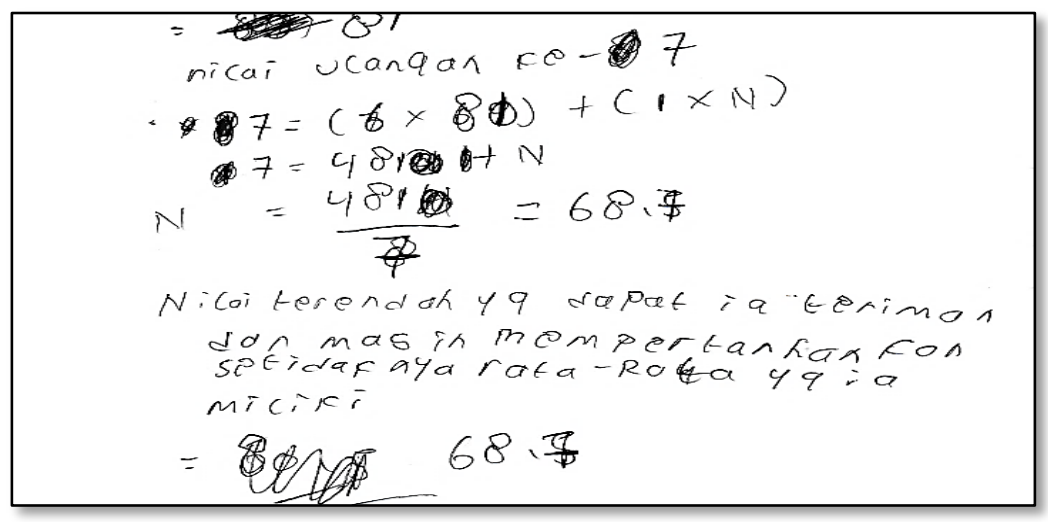

Gambar 7. Hasil pekerjaan S13. 
Penelitian ini sejalan dengan penelitian yang dilakukan oleh Yanti \& Syazali (2016) yang mendapatkan perbedaan setiap subjek dalam menyelesaikan permasalahasn yang berkaitan dengan proses berpikir yaitu konseptual, semikonseptual, dan komputasional. Selain itu, penelitian ini juga sejalan dengan penelitian menurut Istiqomah \& Rahaju (2014) yang menyatakan bahwa penyelesaian masalah lebih cenderung menggunakan proses bepikir semikonseptual. Kemudian, dapat dilihat dari hasil dan pembahasan yang telah dianalisis, mahasiswa yang memiliki proses berpikir semikonseptual lebih cenderung memilki kemampuan sedang. Pernyataan ini sejalan dengan penelitian yang dilakukan oleh Nafi'an (2016) yang menyatakan bahwa untuk kelompok mahasiswa yang berkemampuan sedang cenderung memiliki proses berpikir semikonseptual. Penelitian ini akan sangat berguna untuk melatih proses berpikir mahasiswa agar memahami soal yang diberikan secara lebih teliti, serta dapat menyelesaikan permasalahan berkaitan dengan soal cerita statistika.

\section{KESIMPULAN DAN SARAN}

Berdasarkan hasil penelitian yang telah dilakukan, dapat disimpulkan bahwa 13 subjek memiliki proses berpikir yang berbeda-beda baik dari segi pemahaman maupun strategi yang digunakan. Dari segi pemahaman, terdapat satu orang subjek yang memiliki proses berpikir konseptual yaitu S1, dan sisanya masih dengan proses berpikir semikonseptual. Begitu juga pada strategi yang digunakan, terdapat satu orang subjek dengan proses berpikir yang konseptual yaitu
S1 itu sendiri dan sisanya juga dengan proses berpikir semikonseptual.

Saran yang sesuai dengan penelitian yang dilakukan yaitu perlu adanya penelitian lanjutan untuk mengetahui lebih lanjut dan membuktikan apakah benar mahasiswa lebih banyak yang memilki proses berpikir semikonseptual dengan berbagai soal yang berkenaan dengan proses berpikir mahasiswa.

\section{DAFTAR PUSTAKA}

Amir, M. F. (2015). Proses berpikir kritis siswa sekolah dasar dalam memecahkan masalah berbentuk soal cerita matematika berdasarkan gaya belajar. JURNAL MATH EDUCATOR NUSANTARA: Wahana Publikasi Karya Tulis Ilmiah di Bidang Pendidikan Matematika, 1(2).

Cai, J., \& Lester, F. (2010). Why is teaching with problem solving important to student learning. National council of teachers of mathematics, 13(12), 1-6.

Chukwuyenum, A. N. (2013). Impact of critical thinking on performance in mathematics among senior secondary school students in Lagos State. IOSR Journal of Research \& Method in Education, 3(5), 18-25.

Farida, N. (2015). Analisis kesalahan siswa SMP kelas VIII dalam menyelesaikan masalah soal cerita matematika. AKSIOMA: Jurnal Program Studi Pendidikan Matematika, 4(2), 42-52.

Hartono, Y. (2014). Matematika strategi pemecahan masalah. Yogyakarta: Graha Ilmu. 
Hidayah, S. (2016). Analisis kesalahan siswa dalam menyelesaikan soal cerita SPLDV berdasarkan langkah penyelesaian Polya. Jurnal Pendidikan, 1 .

Indrawati, K. A. D., Muzaki, A., \& Febrilia, B. R. A. (2019). Profil berpikir siswa dalam menyelesaikan soal sistem persamaan linear. Jurnal Didaktik Matematika, 6(1), 6883.

Istiqomah, N. \& Rahaju, E. B. (2014). Proses berpikir siswa sekolah menengah pertama (SMP) dalam menyelesaikan soal cerita matematika berdasarkan gaya kognitif pada materi bangun ruang sisi lengkung. MATHEdunesa, 3(2).

Kafiar, E., Kho, R., \& Triwiyono, T. (2015). Proses berpikir siswa SMA dalam memecahkan masalah matematika pada materi SPLTV ditinjau dari gaya kognitif field independent dan field dependent. Jurnal Ilmiah Matematika dan Pembelajarannya, 2(1).

Karnasih, I. (2015). Analisis Kesalahan Newman Pada Soal Cerita Matematis (Newmans Error Analysis In Mathematical Word Problems). Jurnal Paradikma, 8(1), 37-51.

Laily, I. F. (2014). Hubungan Kemampuan Membaca Pemahaman dengan Kemampuan Memahami Soal Cerita Matematika Sekolah Dasar. Eduma: Mathematics Education Learning and Teaching, 3(1).

Marlina, L. (2013). Penerapan Langkah Polya dalam Menyelesaikan Soal Cerita Keliling dan Luas Persegi Panjang. Jurnal
Elektronik Pendidikan Matematika Tadulako, 1(1), 4352.

Nafi'an, M. I. (2017). ANALISIS BERPIKIR KONSEPTUAL, SEMIKONSEPTUAL DAN KOMPUTASIONAL SISWA SD DALAM MENYELESAIKAN SOAL CERITA. JP2M (Jurnal Pendidikan dan Pembelajaran Matematika), 2(2), 72-78.

Ngilawajan, D. A. (2013). Proses berpikir siswa SMA dalam memecahkan masalah matematika materi turunan ditinjau dari gaya kognitif field independent dan field dependent. PEDAGOGIA: Jurnal Pendidikan, 2(1), 71-83.

Ramalisa, Y. (2013). Proses berpikir kritis siswa SMA tipe kepribadian thinking dalam memecahkan masalah matematika. Edumatica: Jurnal Pendidikan Matematika, 3(01).

Retna, M., \& Mubarokah, L. (2013). Suhartatik. 2013. Proses berpikir siswa dalam menyelesaikan soal cerita ditinjau berdasarkan kemampuan matematika (The student thinking process in solving math story problem). Jurnal Pendidikan Matematika STKIP PGRI Sidoarjo, 1(2), 7182.

Rindyana, B. S. B., \& Chandra, T. D. (2012). Analisis kesalahan siswa dalam menyelesaikan soal cerita matematika materi sistem persamaan linear dua variabel berdasarkan analisis Newman (Studi Kasus MAN Malang 2 Batu). Artikel Ilmiah Universitas Negeri Malang, 1(2). 
DOI: https://doi.org/10.24127/ajpm.v8i3.2270

Rizal, M. (2011). Proses Berpikir Siswa SD Berkemampuan Matematika Tinggi Dalam Melakukan Estimasi Masalah Berhitung. In Prosiding Seminar Nasional Penelitian, Pendidikan, dan Penerapan MIPA Tanggal (Vol. 14, pp. 19-28).

Safrida, L. N., Susanto, S., \& Kurniati, D. (2015). Analisis Proses Berpikir Siswa Dalam Pemecahan Masalah Terbuka Berbasis Polya Sub Pokok Bahasan Tabung Kelas IX SMP Negeri 7 Jember. Kadikma, 6(1).

Sirait, N., Jamiah, Y., \& Suratman, D. (2017). Proses Berpikir Siswa dalam Menyelesaikan Soal Cerita pada Materi Spltv di SMA. Jurnal Pendidikan Dan Pembelajaran, 6(11).

Siswono, T. Y. E. (2016). Proses Berpikir Kreatif Siswa dalam Memecahkan dan Mengajukan Masalah Matematika. Jurnal Ilmu Pendidikan, 15(1).

Susiana, E. (2010). IDEAL Problem Solving dalam Pembelajaran Matematika. Kreano, Jurnal Matematika KreatifInovatif, 1(2), 73-82.

Yanti, A. P., \& Syazali, M. (2016). Analisis proses berpikir siswa dalam memecahkan masalah matematika berdasarkan langkah-langkah Bransford dan Stein ditinjau dari Adversity Quotient. Al-Jabar: Jurnal Pendidikan Matematika, 7(1), 63-74 